\title{
THE BEST
}

Now in paperback...

Citizens of the World London Merchants and the Integration of the British Atlantic Community, 1735-1785

\section{David Hancock}

"... Hancock tackles a wildly ambitious topic-and succeeds brilliantly.... must reading for every scholar interested in the complex institutional structure of the North Atlantic economy in the eighteenth-centuryand in the evolution of the increasingly interactive international economy over the last three bumdred years."

- Business History Review
$62942-x$
Paperback
about $\$ 18.95$

\section{Politics, Religion and the} British Revolutions

The Mind of Samuel Rutherford John Coffey

This book is the first modern intellectual biography of the Scottish theologian and political theorist Samuel Rutherford (c. 1600-1661). It provides a thorough discussion of Rutherford's religious and political ideas, and their role in the ideology of the Scottish Covenanters whose rebellion against Charles I marked the beginning of the British troubles in the mid-seventeenth century.

Cambridge Studies in Early Modern British History

58172-9 Hardback

$\$ 59.95$

\section{Print Politics}

The Press and Radical Opposition in Early Nineteenth-Century England Kevin Gilmartin

This book is the first literary study of the culture of the popular radical movement for parliamentary reform in the early decades of the nineteenth century. It explores the styles and strategies of radical opposition in the periodical press and in the public culture of the time.

Cambridge Studies in Romanticism 21

49655-1 Hardback \$59.95

\section{Britain and the Spanish Civil War Tom Buchanan}

No foreign conflict has had a greater impact on modern British politics than the Spanish Civil War (1936-9). Buchanan draws heavily on new archival sources to reinterpret familiar aspects of this war, such as the role of the British government, the intellectuals, and the International Brigades, as well as to shed light on previously neglected subjects such as right-wing and religious opinion.
45500-6
Hardback
$\$ 64.95$
45569-3 Paperback \$24.95

\section{Press Censorship in Elizabethan England Cyndia Susan Clegg}

This is a revisionist history of press censorship in the rapidly expanding print culture of the sixteenth century. Clegg establishes the nature and source of the controls, and evaluates their means and effectiveness. By considering the literary and bibliographical evidence of books that were censored, and placing them in the literary, religious, economic and political culture of the time, Clegg concludes that press control was neither a routine nor a consistent mechanism.
57312
Hardback
$\$ 59.95$

\section{The Project of Prose in Early Modern Europe and The New World \\ Elizabeth Fowler and \\ Roland Greene, Editors}

What were the possibilities of prose as a literary medium in the sixteenth and seventeenth centuries? And how did it operate in the literary and social worlds? This book brings together ten new essays by leading scholars to answer these questions.

Contributors: Roland Greene, Elizabeth Fowler, Ronald W. Sousa, Paula Blank, Stephanie H. Jed, David Scott Kastan, Timothy Hampton, William H. Sherman, Ann Rosalind Jones, Amy Boesky, Rolena Adorno

Cambridge Studies in Renaissance Literature and Culture 16

44112-9 Hardback \$59.95 


\section{FROM CAMBRIDGE}

The Culture of Slander in Early Modern England M. Lindsay Kaplan

Slander constitutes a central social, legal and literary concern of early modern England. Kaplan reveals it to be an effective, if unstable, means of repudiating one's opposition, and shows how it was deployed by rulers and poets including Spenser, Jonson and Shakespeare. She challenges recent claims that the state controlled poets' criticisms by means of censorship.

Cambridge Studies in Renaissance Literature and Culture 19

58408-6 Hardback \$49.95

\section{Courtly Letters in the Age of Henry VIII}

Literary Culture and the Arts of Deceit

\section{Seth Lerer}

This revisionary study of the origins of courtly literature reveals the culture of spectatorship and voyeurism that shaped early Tudor English literary life. Through new research into the reception of Chaucer's Troilus and Criseyde, it demonstrates how Pandarus became the model of the early modern courtier.

Cambridge Studies in Renaissance Literature and Culture 18

59001-9 Hardback \$59.95

\section{Britain and}

\section{Indian Nationalism}

The Imprint of Ambiguity 1929-1942

\section{D.A. Low}

On the eve of the fiftieth anniversary of Indian independence Low examines anew the distinctive character of perhaps the most momentous struggle of the twentieth century. He shows how the struggle was conditioned by the ambiguity of the British position, determined to hold fast to their Indian empire yet reluctant to offer unyielding resistance to their nationalist opponents. 55017-3 Hardback \$74.95

\section{Capitalism in Contention}

Business Leaders and Political

Economy in Modern Britain

Jonathan Boswell and James Peters

This book examines the ideas of business leaders on political, economic and ethical issues in modern Britain. Drawing on hitherto unexplored records and wide-ranging interviews, the book sheds new light on the Wilson, Heath and Thatcher periods, the "mixed economy" and the "New Right," the peak representative organizations of business, and business relationships with government. 58225-3 Hardback about $\$ 59.95$ 58804-9 Paperback about $\$ 19.95$

\section{Religion and Culture in Renaissance England Claire McEachern and Debora Shuger, Editors}

Essays by leading historians and literary scholars investigate the role of religion in shaping political, social, and literary forms.

Contributors: Claire McEachern, Patrick Collinson, David Scott Kastan, Jesse Lander, Lowell Gallagher, Debora Shuger, William J. Bouwsma, Janel Mueller, Richard McCoy, Michael Schoenfeldt, Robert N. Watson, Richard Strier

58425-6 Hardback \$59.95

\section{Reading Old English Texts Katherine O'Brien O'Keeffe, Editor}

This book focuses on the critical methods currently being used and developed for reading and analyzing writings in Old English. It is the first collection of its kind in the field and is a timely book, given the explosion of interest in the theory, method and practice of critical reading in recent years.

Contributors: Katherine O'Brien O'Keeffe, Michael Lapidge, D.G. Scragg, Daniel Donoghue, Nicholas Howe, Andy Orchard, Paul E. Szarmach, Peter S. Baker, Clare A. Lees, Carol Braun Pasternack

46575-3 Hardback \$59.95 46970-8 Paperback \$18.95 


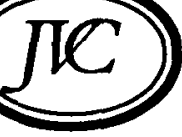

Volume 2, 1997

ISSN 1355-5502

2 issues yearly

\section{Selected articles}

Blindness and Insight: Millais'

The Blind Girl and the

limitations of representation (Kate Flint)

Divine Hunger: culture and the commodity in Rider

Haggard's She (Robent Michalski)

Being in debt in Dickens' London: fact, fictional representation and the nineteenth-century prison (Margot Finn)

The English Face of Karl Marx (Miles Taylor)

\section{Explore the Victorian era with}

Journal of

\section{Victorian Culture}

Journal of Victorian

Culture is interdisciplinary

and eclectic, publishing work by established scholars alongside innovative newcomers. Established in Spring 1996, the journal is edited and published in Britain with the assistance of a distinguished group of Editorial Consultants. It provides an international forum for the exchange of information, discussion, and debate on all aspects of Victorian history and culture, acting as a vital focus for contemporary scholarly activity in this extremely diverse field.
Journal of Victorian Culture encompasses the various disciplines which have traditionally constituted Victorian Studies:

- Architectural history

\% Cultural studies

* Economic and social history

* The history of science and rechnology

Literary studies

\% Music

* Popular culture

Theatre

* The visual arts

Please enter my subscription to JVC Volume 2

ISSN 1355-5502

\section{Institutions}

\section{UK and EC} $£ 30.00$

- North America

Rest of World

$\$ 58.00$

$E 34.00$

\section{Individuals}

c UK and EC

$£ 15.00$

North America $\$ \mathbf{\$ 2 9 . 0 0}$

Rest of World $£ 17.00$

Please send me a free sample copy

Back issues are available from Edinburgh

University Press

\section{Order Form}

Please return to the address below JVC707/JBS

Surface postage is included in the subscription. Please add $65 \$ \$ 10$ for airmail delivery.

Name

Address

\section{Postcode}

Tel. Fax

I enclose a deque made payable to Edinburgh University Press

Please debit my Visa/Mastercard

Card No.

Expiry Date I

Signature

Edinburgh University Press, 22 George Square, Edinburgh, EH8 9LF Tel: (00 44) 131 6506207 Fax: $(0044) 1316620053$ http://www.eup.ed.ac.uk/ 


\section{NEW TITLES IN BRITISH STUDIES}

\section{HOPE AND GLORY BRITAIN 1900-1990}

Peter Clarke. "While the reading public for which this series is designed will be borne smoothly along on the wonderfully easy flow of Clarke's prose, fellow professionals will pause frequently to relish the skill with which he manages the transitions between topics and themes which a general survey continually requires."-The Times Literary Supplement. 464 pp.

Penguin

0-14-014830-2

$\$ 14.95$

\section{A MONARCHY TRANSFORMED BRITAIN 1603-1714}

Mark Kishlansky. "Mark Kishlansky has provided the animated, lucid, and up-todate narrative that we need." - The Sunday Telegraph.

Penguin

$0-14-014827-2$ $\$ 14.95$

\section{THE PENGUIN BOOK OF RESTORATION VERSE}

Edited with an Introduction by Harold Love. This comprehensive new volume of Restoration poetry includes such authors as Milton, Dryden, Marvell, and Aphra Behn, reflecting recent development in period scholarship and featuring many works by women poets, as well as much verse from the subversive scribal tradition. $384 \mathrm{pp}$.

Penguin Classic $\quad 0-14-042407-5 \quad \$ 14.95$

\section{GEORGE ELIOT: A LIFE}

Rosemary Ashton. "It is tempting to think of George Eliot (1819-1880) as better matched to our century than her own. But Ashton's biography draws widely from Eliot's letters and from those of her contemporaries to provide a rich social context for a woman who embraced change, but seldom advertised it."Publishers Weekly. 480 pp.
Allen Lane
0-713-99194-1
$\$ 32.95$

\section{A CENTURY OF WOMEN THE HISTORY OF WOMEN IN BRITAIN AND THE UNITED STATES}

Sheila Rowbotham. "We can thank our stars for Sheila Rowbotham, who has written an almost improbably lively, readable, and balanced account of the gender wars of one messy century....Its power lies in its showing that the momentous changes women now enjoy came to us not from the top down, but rather from the thousands of petty heroisms of thousands of tired individual women who each gave the cause of female freedom that one last push."-Naomi Wolf, The Times (London). $736 \mathrm{pp}$.

Viking

0-670-87420-5

$\$ 34.95$

\section{SELECTIONS FROM}

\section{THE TATLER}

\section{AND THE SPECTATOR}

Richard Steele and Joseph Addison. Edited with an Introduction by Angus Ross. Light in tone but heavy in influence, the essays published in The Tatler and The Spectator examined everything from morality to philosophy and science. This collection-organized under such subjects as "Men, Women and Manners," "Politics and Public Affairs," and "Essays in Criticism" - sheds light on the ideas at the heart of 18th-century thought both in England and in Europe. 592 pp.

Penguin Classic 0-14-043298-1

$\$ 13.95$

\section{QUEEN VICTORIA}

Lytton Strachey. An intimate portrait that dispelled the image of Victoria as a cold, remote, and priggish woman, and influenced both in style and content all subsequent biographical works. $256 \mathrm{pp}$.

Penguin Classic $\quad 0-14-018393-0 \quad \$ 12.95$

For a free History catalog, please call 212-366-2372 


\section{THE ENGLISH HISTORICAL REVIEW}

First published in 1886, The English Historical Review is the oldest journal of historical scholarship in the English-speaking world. It deals not only with British history, but with almost all aspects of European and world history since the classical era: it covers the history of the Americas, including the foreign policy of the USA and her role in the wider world, but excludes the domestic history of the USA since Independence, for which other scholarly outlets are plentiful.

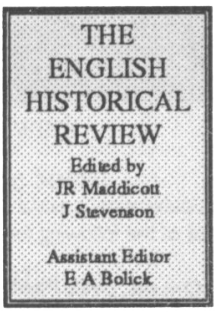

With contributions from around the world, each issue includes major Articles, 'Notes and Documents', and Debates on medieval and modern themes. The joumal also features an unrivalled range and quantity of reviews of books published worldwide.

\begin{tabular}{|lllll|}
\hline $\begin{array}{l}\text { Subscription Details } \\
\text { Volume 112, 1997 }\end{array}$ & UK & Europe & R.o.W. & USA/Can \\
(5 issues) & & & & \\
Annual Subscriptions & & & & \\
Standard & $£ 86$ & $£ 91$ & $£ 95$ & $\$ 160$ \\
Student & $£ 45$ & $£ 50$ & $£ 50$ & $\$ 84$ \\
Single issues & $£ 22$ & $£ 22$ & $£ 24$ & $\$ 41$ \\
ISSN 0013-8266 & & & & \\
\hline
\end{tabular}

\section{FREE ISSUE OFFER}

a Please send me a FREE sample issue of

The English Historical Review, without obligation to subscribe.

Return to: Janice Calleja, Addison Wesley Longman, Higher Education division, Edinburgh Gate, Harlow, Essex

CM20 2JE.

Tel 01279 623207; Fax 01279623862 ,

e-mail: janice.calleja@awl.co.uk

Name:

Address:

Journal of British Studies

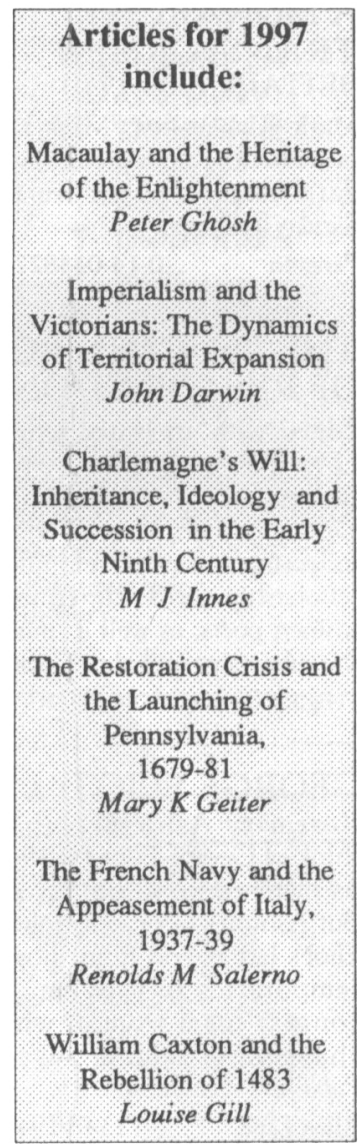

Addison Wesley 


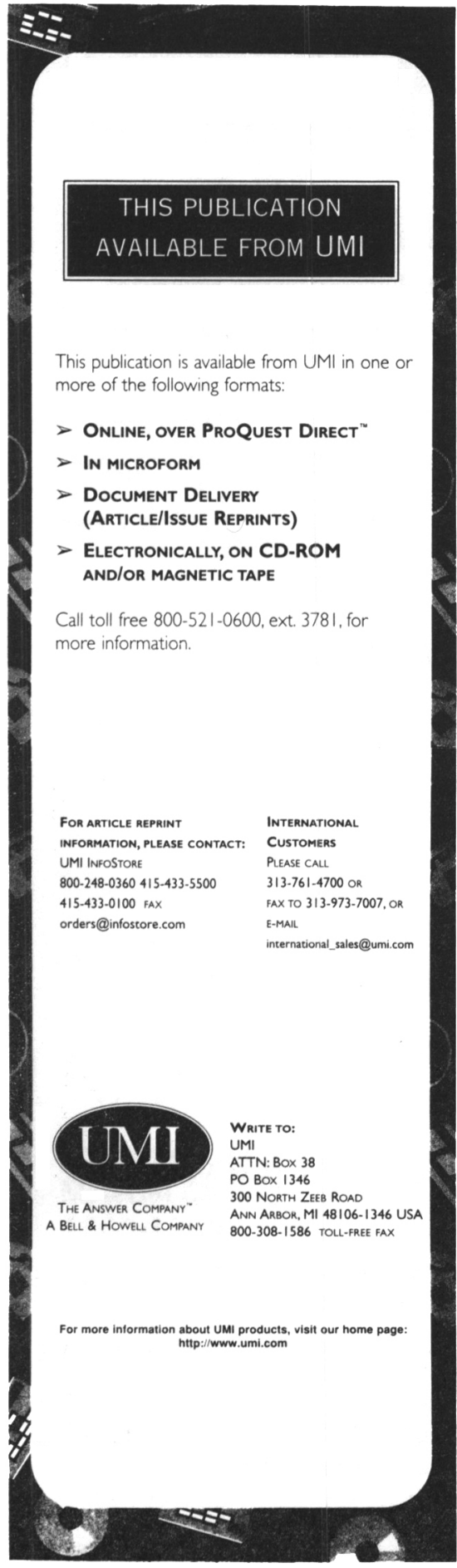

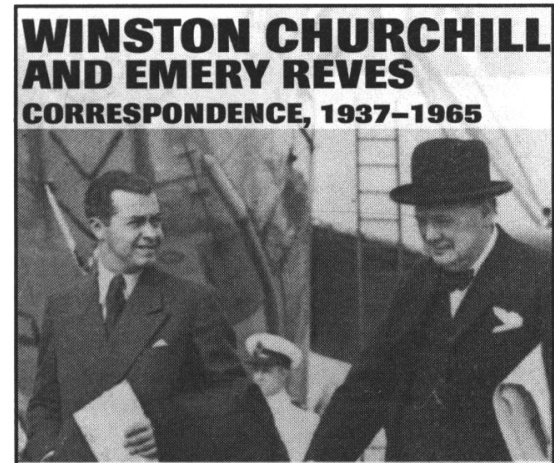

Edited with an introduction and notes by Martin Gilbert

Early in 1937, the enterprising owner of an independent press service made Winston Churchill an irresistible offer. He would place Churchill's articles on current world events in major newspapers across Europe - and for significantly more money than Churchill's present agent. "I am absolutely convinced," Emery Reves assured Churchill, "that you will find the diffusion of your articles satisfactory."

So began a profitable business relationship that grew into an enduring personal friendship. In this book, Martin Gilbert chronicles that relationship through the correspondence of Winston Churchill and Emery Reves. He preserves a compelling record of how each man used the other's talents to forward a cause that passionately engaged them both - the spread of democratic ideals in a post-totalitarian world.

The correspondence ranges from short notes to lengthy letters and reveals the important role that Reves played in Churchill's writing life. Before World War II, Reves worked untiringly to place Churchill's pro-democracy articles in newspapers around the world. After the war, he acted as agent and editor for Churchill's war memoirs and his four-volume History of the English-Speaking Peoples and ultimately made Churchill one of the highestpaid authors of nonfiction in the twentieth century. The Churchill-Reves correspondence will be essential reading for all students and scholars of the Churchill era.

8 b\&w photos, 2 maps, $\$ 39.95$ hardcover

At bookstores, or call 800-252-3206.

\section{University of Texas Press} Box 7819•Austin, TX 78713 http://www.utexas.edu/utpress/

Emery Reves meets Winston Churchill as he arrives at Le Bourget airport, Paris, October 1938 


\section{HISTORICAL REFLECTIONS/ RÉFLEXIONS HISTORIQUES}

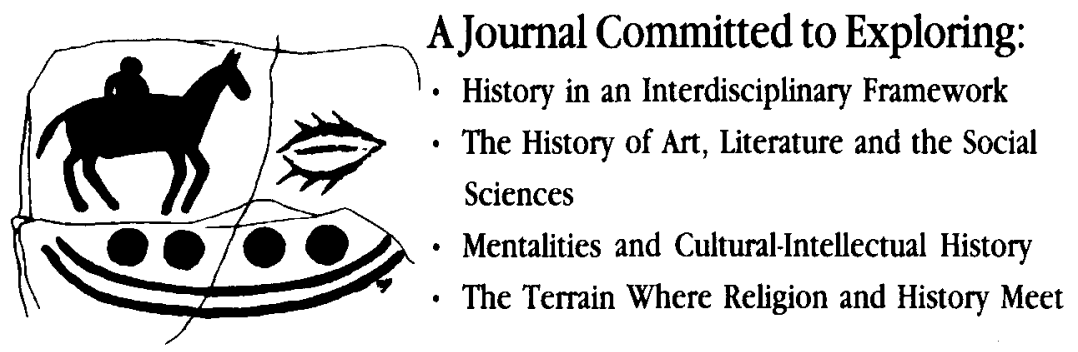

\section{RECENT SPECLI ISST ES}

- Patrick Hutton

Dohn Gilmour

D Joel Blatt
Vico for Historians

Nietzsche: Voices, Masks and Histories

The French Defeat of 1940: Reassessments

\section{FORTICONINGGARTICLS}

Leslie Choquette

- Robert Anchor

- Paul Mazgaj

Mary Pickering
"Degenerate or Degendered? Images of Prostitution in the French Third Republic"

"Motherhood and Family in Goethe's Faust"

"The 'Romantic Fascism' of Robert Brasillach"

"Rhetorical Strategies in the Work of Auguste Comte"

HR/RH appears three times a year with an annual subscription rate of $\$ 45$ for institutions and $\$ 26$ for individuals.

Send inquiries to:

The Editor

HISTORICAL REFLECTIONS/REFLEXIONS HISTORIQUES

Division of Human Studies, Kanakadea Hall

Alfred University

Alfred, NY 14802 


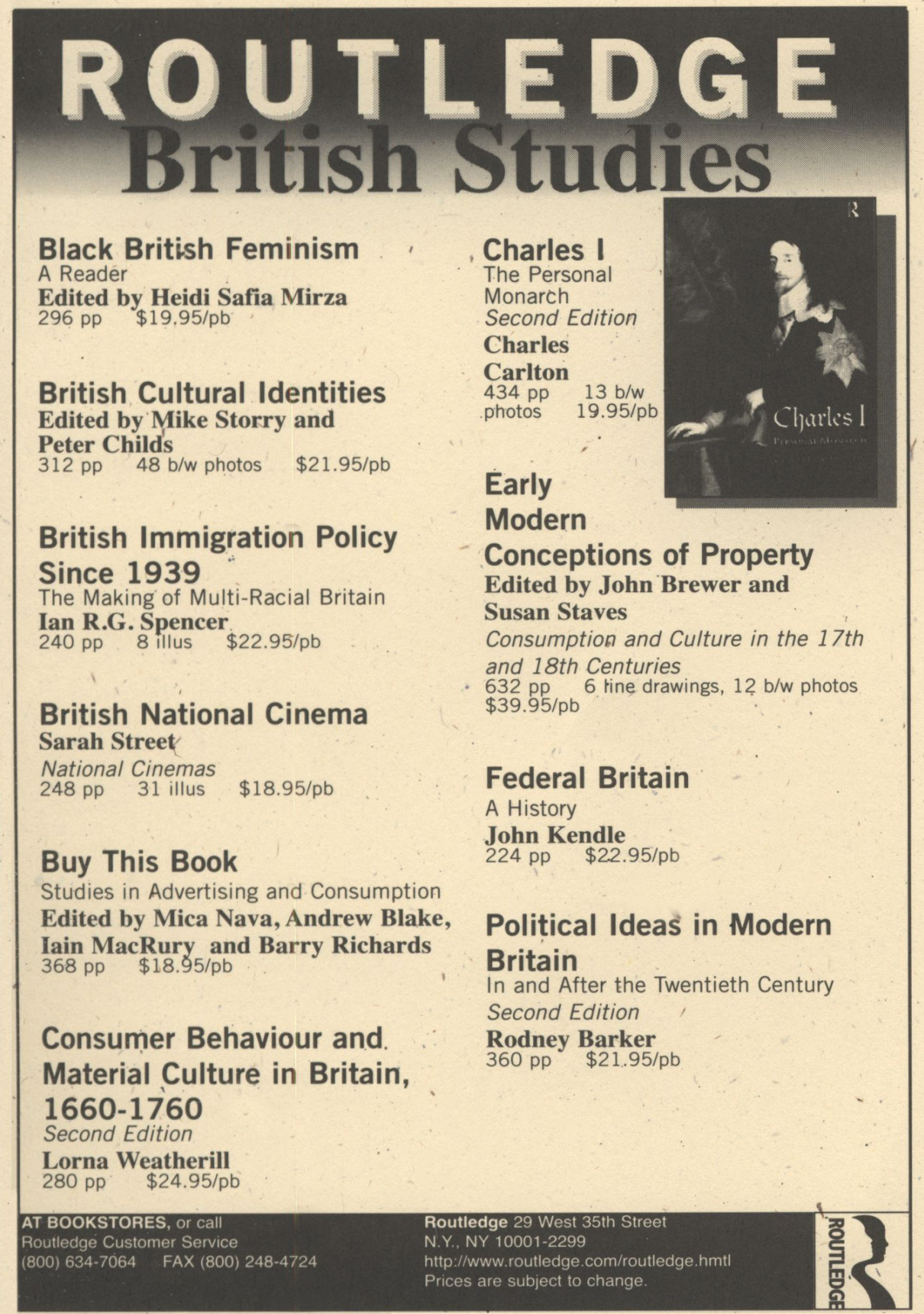




\section{Hogarth and His Times}

\section{David Bindman}

In this catalog and the exhibition it accompanies, Bindman works backward from Hogarth's reputation today-where he is seen by some as a conservative populist and by others as a political radical - and examines his impact on "

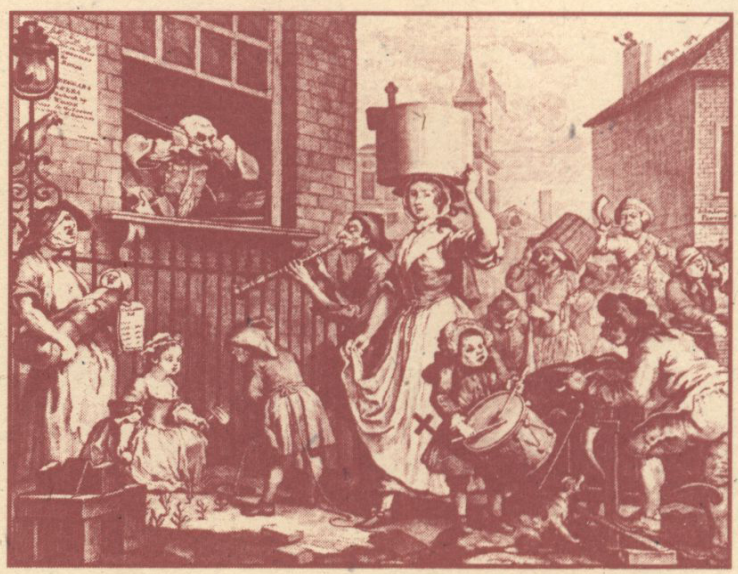
various artists over the past three centuries. $\$ 45.00$ cloth, $\$ 29.95$ paper, illustrated

\section{J.M.W. Turner}

Romantic Painter of the Industrial Revolution William S. Rodner J.M.W. Turner is known and admired for portraying the transcendent power and turbulence of nature in his paintings of landscapes and storms at sea. But, as Rodner's beautifully illustrated book makes clear, Turner also drew inspiration from the sweeping new . forces of the Industrial Revolution.

$\$ 45.00$ clogh , illustrated

\section{At the Heart of the Empire}

Indians and the Colonial Encounter in

Late-Victorian Britain

\section{Antoinette Burton}

Burton focuses on the experiences of three

Victorian travelers in Britain to illustrate how "Englishness" was made and remade in relation to imperialism. She shatters the myth of Britain's insularity from its own construction of empire and shows that it was instead a terrain open to continual contest and refiguration.' $\$ 55.00$ cloth, illustrated

New in paperback

The Unruly Queen

The Life of Queen Caroline

Flora Fraser

"A complete and well-documented account [that] tells the story of a marginal woman and a near-tragic queen."

- New York Times

Book Review

"A squalid tale superbly told:"

- Sunday Times

(London)

$\$ 17.95$ paper, illustrated

www.ucpress.edu At bookstores or order 1-800-822-6657.

University of California Press 